\title{
EVALUATION OF THE EFFECT OF MATRINE ON HUMAN LARYNGEAL SQUAMOUS CELL CARCINOMA CELL LINE
}

\author{
Enas Alaa El-din Abd El-Aziz *
}

\begin{abstract}
Aim of study: to evaluate the possible anticancer potential of Matrine, one of the main active components extracted from dry roots of Sophora flavescens Ait (Leguminosae), on human laryngeal squamous cell carcinoma cell line (Hep-2).
\end{abstract}

Material and methods: Prepared (Hep-2) cell line was treated with different concentrations of Matrine for 48 hours. The effect of Matrine on cell line was investigated using MTT assay, cytological examination and nuclear morphometric analysis of treated cells to explore the effect of the drug on cell proliferation and induction of apoptosis. The results were analyzed statistically. $P$ value $\leq 0.05$ was considered significant.

Results: MTT assay showed that the proliferation of Matrine treated cells (in relation to control cells) decreased in a dose dependent manner. Morphometric analysis showed a decrease in nuclear area factor (NAF), which is an indicator of apoptosis, as concentrations increased. The results were statistically significant.

Conclusion: Matrine has a cytotoxic effect on Hep-2 cell line through induction of apoptosis.

KEYWORDS Matrine, apoptosis, laryngeal carcinoma.

\section{INTRODUCTION}

The most common type of laryngeal cancer is squamous cell carcinoma. Laryngeal carcinoma represents the second most prevalent malignancy of the upper aerodigestive tract (Siegel RL et al., 2016).

Worldwide data proved that cancer of the larynx represents $30 \%$ to $40 \%$ of all neoplastic head and neck tumors and $1 \%$ to $2.5 \%$ of all malignant tumors in the human body (Bray F et al., 2001).
Both smoking and heavy consumption of alcohol are important risk factors of laryngeal cancer (Ridge JA et al., 2010). The disease is more common in males. About $10 \%$ of patients with laryngeal squamous cell carcinoma are younger than 40 years of age (Singh B et al., 2000).

Attention has been focused on natural compounds for their use in cancer treatment because they represent a rich source of products that have cytotoxic effect on malignant cells without side

\footnotetext{
* Lecturer of Oral and Maxillofacial Pathology, Faculty of Dentistry, Minia University.
} 
effects on normal cells. More than $70 \%$ of anticancer materials are either natural products or substances derived from natural products (Karikas $G A, 2010$ ).

Sophora flavescens, with the active constituent Matrine, is a traditional Chinese medicine with significant inhibitory activity against malignant tumors. (Liu XY et al., 2008).

Matrine inhibits the expression of substance $\mathrm{p}$ receptor and regulates inflammatory cytokine production. Thus, it's used as anti-inflammatory drug (Hu ZL et al., 1996). Moreover, it promotes apoptosis in leukemia cells through inhibition of NF- $x \beta$ pathway and multiple receptor tyrosine kinase activation in vitro (Luo C et al., 2007).

Other physiological and pharmacological uses of Matrine include antifibrosis, antioxidative, and immune regulation (Lao Y, 2005; Huang $S$ et al., 2011).

The present study was conducted to show if Matrine has an effect on the proliferation and apoptosis of laryngeal squamous cell carcinoma cell line (Hep-2).

\section{MATERIAL AND METHODS}

\section{Cell line:}

Hep-2 cells were imported from the "American type Culture Collection (ATCC)" in the form of frozen vial with the reference number "CCI-23".

\section{Drug:}

Matrine (ab142910) was purchased from Abcam (UK) with molecular formula of $\mathrm{C}_{15} \mathrm{H}_{24} \mathrm{~N}_{2} \mathrm{O}$ and molecular weight of 248.36. It was dissolved in DMSO and adjusted to the final concentration with culture medium.

\section{Preparation of cell monolayer and cell line treatment}

Cell culture was grown in the recommended medium with $10 \% \mathrm{FBS}$ and incubated in $5 \% \mathrm{CO}_{2}$ at $37^{\circ} \mathrm{C}$. Hep- 2 cells were cultured overnight in 96-well plates. Cells were treated with a 2 -fold serially diluted test material starting from 20 to 0.31 $\mathrm{mg}$. Maintenance medium containing DMSO as a negative control was considered. Treated cells were incubated at $37^{\circ} \mathrm{C}$ for 48 hours.

\section{Evaluation of viability using MTT assay}

The effect of different concentrations of Matrine on viability of treated cells was examined using MTT assay. The number of living cells in each sample was determined from its absorbance at $570 \mathrm{~nm}$ (A570) using the Dynatech MR5000 spectrophotometer (Dynatech Laboratories, Inc., Chantilly, VA). The data obtained were analyzed using Master Plex Reader Fit program to determine $\mathrm{IC}_{50}$, The half maximal inhibitory concentration, of the drug. Cells were then treated for $48 \mathrm{~h}$ with pre $\mathrm{IC}_{50}, \mathrm{IC}_{50}$ and post $\mathrm{IC}_{50}$ concentrations of Matrine which were determined depending on the results of MTT assay for further assays.

\section{Morphological Evaluation of treated cells}

Pelleted cells were re-suspended in PBS and a part $(50 \mu \mathrm{L})$ was dispended on the clean ethanol washed glass slide, air dried and fixed using methanol as a preparatory step for cytological examination after staining with H\&E.

\section{Morphometric analysis:}

Ten microscopic fields of each slide were photomicrographed at the power of $1000 \mathrm{X}$ oil immersion. The images were transferred to the computer system for analysis using image analysis software (Image J, 1.27z, NIH, USA).

The surface area and nuclear circularity were measured. Nuclear area factor (NAF) was calculated using the formula: NAF $=$ Circularity $\times$ Object area .

\section{Statistical analysis:}

The mean NAF values were assessed statistically. Data entry and analysis were all done with IBM compatible computer using software called SPSS for windows version 22 . 
One-way ANOVA test was used to determine the overall statistically significant difference in all group means. Post hoc tests were run to confirm where the differences occurred between groups using the Statistical Package for Social Science software (SPSS) for Windows version 22. The results were considered significant when $\mathrm{P}$ value $\leq 0.05$.

\section{RESULTS}

\section{A-MTT Assay:}

Data obtained revealed a decrease in the viability of Hep-2 treated cells with increasing the dose from $0.31 \mathrm{mg}$ to $20 \mathrm{mg}$ (table 1 ). The half-maximal inhibitory concentration, $\mathrm{IC}_{50}$ was calculated using Master Plex Reader Fit program recording a value of $3 \mathrm{mg}$.

\section{B-Microscopic examination:}

Control cells showed the regular appearance of malignant cells with dysplastic nuclei. Only few cells showed the morphological criteria of apoptosis as shown in fig (1).

Drug treated cells showed morphological criteria of apoptosis which increased as Matrine concentration increased. These criteria included: peripheral chromatin condensation, membrane blebbing, nuclear fragmentation and apoptotic

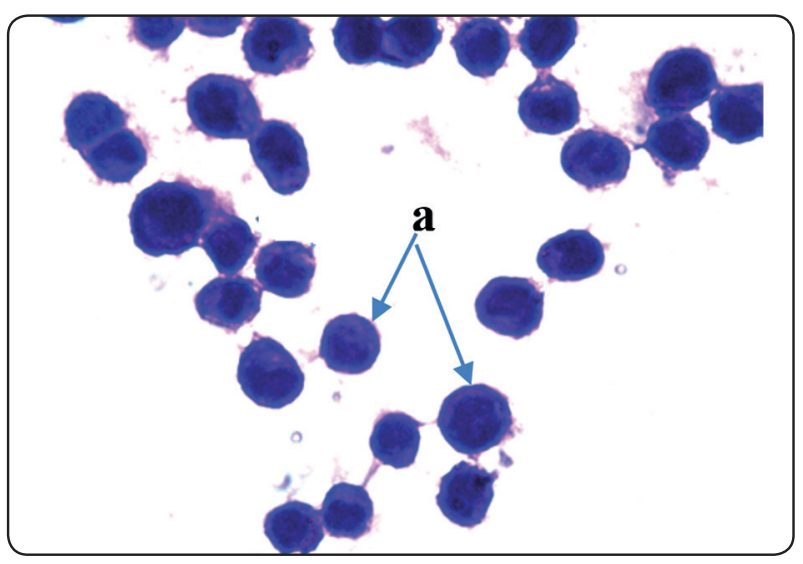

Fig (1): Control Hep-2 cells showing regular cellular outline with hyperchromatic dysplastic nuclei (a). body formation. In addition to these criteria, some cells showed necrotic features as shown in figures (2, 3 and 4).

\section{C- Morphometric analysis:}

i. Circularity: The mean circularity values decreased as the dose of Matrine increased to be 0.514 with pre IC50, 0.463 for IC50 and 0.433 for post IC50 concentrations.

ii. Nuclear surface area: There was a decrease in the mean surface area values from 734 with pre IC50, 627for IC50 to 502 for post IC50.

iii. NAF: The mean values of NAF decreased from 396.338 with pre IC50, 332.61 for IC50 and 252.863 for post IC50.

\section{E- Statistical analysis:}

ANOVA test revealed a statistically significant difference among mean values of NAF of Hep-2 cells treated with different concentration of Matrine and the control cells $(\mathrm{p}$ value $=0.0001)($ table 3$)$.

Post Hoc multiple comparison test (Tukey HSD method) revealed a statistically significant difference when comparing the mean value of NAF of control cells to any drug concentration. There is a statistically significant difference when comparing the mean value of NAF of Matrine concentrations to each other (Table 4).

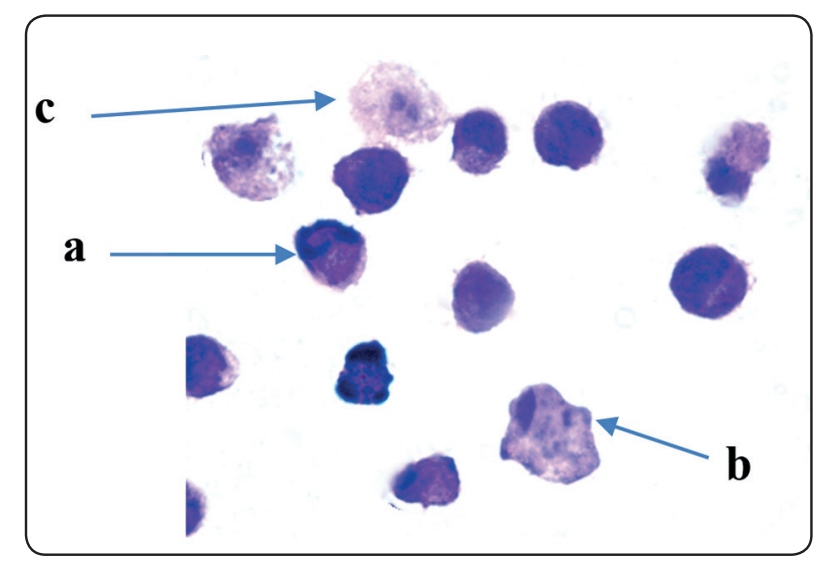

Fig (2): Hep-2 cells 48 hours after treatment with Pre IC50 $(2 \mathrm{mg}$ ) concentration of Matrine showing peripheral chromatin condensation (a), membrane blebbing (b) and necrotic cells (c). 


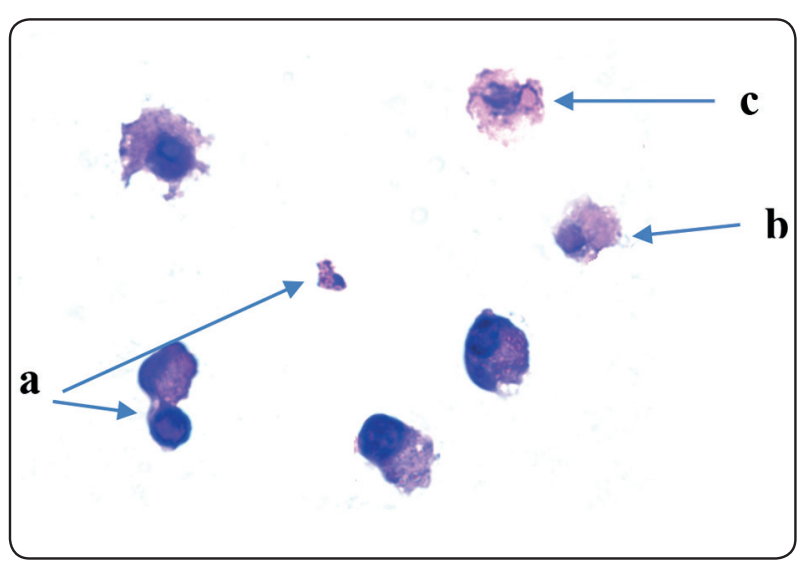

Fig (3): Hep-2 cells 48 hours after treatment with IC50 (3 $\mathrm{mg}$ ) concentration of Matrine showing formation of apoptotic body (a), necrotic cells (b) and peripherial condensation of chromatin (c).

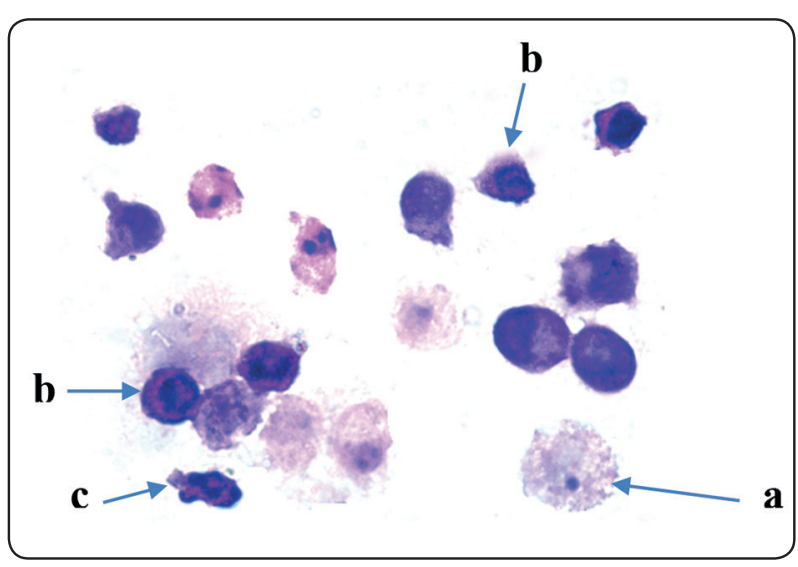

Fig (4): Hep-2 cells 48 hours after treatment with post IC50 (4 mg) concentration of Matrine showing necrotic cell (a), peripheral chromatin condensation (b) and nuclear fragmentation (c).

TABLE (1): The mean viability percentage of Hep-2 cells treated with different concentration of Matrine for 48 hours.

\begin{tabular}{|l|c|c|c|c|c|c|c|}
\hline \multicolumn{1}{|c|}{ Matrine } & 20 & 10 & 5 & 2.5 & 1.25 & 0.62 & 0.31 \\
\hline Voncentration (mg) & 21.43 & 26.03 & 33.33 & 60 & 78.51 & 86.95 & 94.42 \\
\hline
\end{tabular}

TABLE (2): Descriptive statistics of NAF value of control cells and Matrine treated cells with different concentrations

\begin{tabular}{|c|c|c|c|c|c|c|c|c|}
\hline & \multirow[t]{2}{*}{$\mathrm{N}$} & \multirow[t]{2}{*}{ Mean } & \multirow[t]{2}{*}{ Std. Deviation } & \multirow{2}{*}{$\begin{array}{l}\text { Std. } \\
\text { Error }\end{array}$} & \multicolumn{2}{|c|}{$95 \%$ confidence interval for mean } & \multirow[t]{2}{*}{ Minimum } & \multirow[t]{2}{*}{ Maximum } \\
\hline & & & & & Lower bound & Upper bound & & \\
\hline Control & 10 & 609.338 & 36.39284 & 11.5084 & 583.3041 & 635.3719 & 562.23 & 665.63 \\
\hline PreIC $_{50}$ & 10 & 396.61 & 20.22855 & 6.39683 & 382.2904 & 411.2316 & 358.88 & 425.54 \\
\hline & 10 & 332.964 & 27.77279 & 8.78253 & 313.0965 & 352.8315 & 285.76 & 368.59 \\
\hline PostIC $_{50}$ & 10 & 252.863 & 27.94876 & 8.83817 & 232.8697 & 272.8563 & 217.54 & 299.51 \\
\hline Total & 40 & 397.981 & 136.7359 & 21.6198 & 354.2512 & 441.7118 & 217.54 & 665.63 \\
\hline
\end{tabular}

TABLE (3): ANOVA test for the mean values of NAF of different Matrine concentrations and control cells 48 hours post treatment.

\begin{tabular}{|c|c|c|c|c|c|}
\hline \multicolumn{6}{|c|}{ ANOVA } \\
\hline NAF value of treated cells & Sum of Squares & df & Mean Square & $\mathrm{F}$ & Sig. \\
\hline Between Groups & 699597.141 & 3 & 233199.047 & 283.862 & 0.0001 \\
\hline Within Groups & 29574.844 & 36 & 821.523 & & \\
\hline Total & 729171.984 & 39 & & & \\
\hline
\end{tabular}

The result is significant when $p$ value $\leq 0.05$ 
TABLE (4): Multiple comparison Bonferroni post hoc test

\begin{tabular}{|c|c|c|c|c|c|c|}
\hline \multirow[t]{2}{*}{ (I) Groups } & \multirow[t]{2}{*}{ (J) Groups } & \multirow{2}{*}{$\begin{array}{c}\text { Mean Difference } \\
\text { (I-J) }\end{array}$} & \multirow[t]{2}{*}{ Std. Error } & \multirow[t]{2}{*}{ Sig. } & \multicolumn{2}{|c|}{ 95\% Confidence Interval } \\
\hline & & & & & Lower Bound & Upper Bound \\
\hline \multirow[t]{3}{*}{ Control } & Pre IC50 & $212.57700^{*}$ & 12.81814 & 0.0001 & 176.7891 & 248.3649 \\
\hline & IC50 & $276.37400^{*}$ & 12.81814 & 0.0001 & 240.5861 & 312.1619 \\
\hline & Post IC50 & $356.47500^{*}$ & 12.81814 & 0.0001 & 320.6871 & 392.2629 \\
\hline \multirow[t]{2}{*}{ Pre IC50 } & IC50 & $63.79700^{*}$ & 12.81814 & 0.0001 & 28.0091 & 99.5849 \\
\hline & Post IC50 & $143.89800^{*}$ & 12.81814 & 0.0001 & 108.1101 & 179.6859 \\
\hline IC50 & Post IC50 & $80.10100^{*}$ & 12.81814 & 0.0001 & 44.3131 & 115.8889 \\
\hline
\end{tabular}

* The mean difference is significant at the 0.05 level.

\section{DISCUSSION}

The incidence of laryngeal squamous cell carcinoma has enormously increased recently regardless the use of several environmental protection and drug treatment procedures on the patients (Coskun H. et al., 2019).

Despite vast improvement in treatment of laryngeal carcinoma with surgery and chemoradiotherapy, the many adverse effects of these treatments negatively impact the quality of life for the patients (McMullen CP and Smith RV, 2015).

This can be overcome by the use of treatment strategies that target the molecular mechanisms associated with this carcinoma and arrest the disease while maintaining maximal laryngeal function. Recently, there has been great shift towards screening the effect of active ingredients of traditional medicine on cancer.

Matrine, active compound isolated from plants used in traditional Chinese herbal medicine, has wide spectrum of antitumor activity (Yong $\boldsymbol{J}$ et al., 2015; Zhou BG et al., 2018) as it has a potential anti-proliferative effect (Yuming $Z$ et al., 2019).

Recently, no studies have reported the effect of Matrine on laryngeal squamous cell carcinoma. Thus, the present research tried to elucidate the effect and mechanism of action of Matrine on Hep2 cell line.
MTT assay results showed that Matrine has antiproliferative effect on Hep-2 in a dose dependent manner with $\mathrm{IC}_{50}$ of $3 \mathrm{mg}$ after application for 48 hours and this was higher than that used with human myloid leukemia cell line for the same duration (Lin $G$ et al., 2019). This would be possible regarding the difference in the studied cell lines characteristics and aggressiveness and due to the changes that occur in the cells in the course of their cultivation in the laboratory conditions.

MTT assay was not enough to reveal the exact mechanism of action of Matrine as it cannot differentiate between apoptosis and necrosis. This could be elucidated by the further assays.

Cytological examination revealed that Matrine treated cells showed characteristic features of apoptosis and these changes became more obvious with increasing the concentration of the drug.

Although morphological evaluation of treated cells can provide a qualitative assessment of apoptotic cells, studies have shown that using this method alone may underestimate the rate of apoptosis by 2-fold to 3-fold (Garrity MM et al., 2003). Therefore, the present study used a reliable and reproducible method, microscopy and imageanalysis based method, which relies on measuring the geometrics of nuclei such as circularity and surface area and using them to calculate the nuclear area factor which is an early detector of subtle changes indicative for apoptosis (Decoster MA, 2007). 
Morphometric analysis showed that the treated cells exhibited decreased value of NAF, compared with control cells in a dose dependent manner.

Matrine induce apoptosis through activation of telomerase (Zuo GQ et al., 2005), regulation of cyclins, cyclin dependent kinase and cyclin dependent kinase inhibitors ( $\mathbf{S i} \mathbf{W K}$ and Gao $\mathbf{L H}$, 2001), suppression of $\mathrm{C}$-myc and Bcl-2 expression and promotion of $\mathrm{N}$-ras and p53 expression $(\boldsymbol{H u} \boldsymbol{M J}$ et al., 2005).

\section{CONCLUSION}

We could conclude that Matrine inhibits growth of Hep-2 cells through induction of apoptosis. Thus, it may provide a candidate for the development of new therapies for laryngeal cancer.

\section{RECOMMENDATION}

large dose application for long duration is required to gain effect and this requires further studies to design and synthesize Matrine derivatives that can overcome its low therapeutic efficacy.

\section{REFERENCES}

1. Bray F, Ferlay J, Parkin DM and Pisani P, 2001. "Cancer incidence, mortality and prevalence worldwide". International Agency for Research on Cancer, GLOBOCAN 2000: Lyon.

2. Coskun H, Mendenhall WM, Rinaldo A, Rodrigo JP, Suárez C, Strojan P, López F, Mondin V, Saba NF, Shaha AR, Smee R, Takes RP and Ferlito A, 2019. "Prognosis of subglottic carcinoma: Is it really worse?". Head Neck.;41(2):511-521.

3. Decoster MA, 2007. "The nuclear area factor (NAF): a measure for cell apoptosis using microscopy and image analysis". Archives of Pathology \& Laboratory Medicine, 378-384.

4. Garrity MM, Burgart LJ, Riehle DL, Hill EM, Sebo TJ and Witzig T, 2003. "Identifying and quantifying apoptosis: navigating technical pitfalls. Modern pathology". an official journal of the United States and Canadian Academy of Pathology, 16: 389-394.
5. Hu MJ, Zeng H, Zhang YP, Zhang S, Qiao MM and Fu H, 2005. "Synergistic effects of matrine and 5-fluorouracil on tumor growth of implanted gastric cancer in nude mice". Chin J Dig Dis ; 6: 68-71.

6. Hu ZL, Zhang JP, Qian DH, Lin W, Xie WF, Zhang XR and Chen WZ, 1996. "Effects of matrine on mouse splenocyte proliferation and release of interleukin-1 and -6 from peritoneal macrophages in vitro". Acta Pharmacol Sin 17: 259-261.

7. Huang S, Fan W, Peng L and Tian J, 2011. "Meta analysis of compound matrine injection combined with cisplatin chemotherapy for advanced gastric cancer". China J. Chin. Mater. Med. 36, 3198-3202.

8. Karikas GA, 2010. "Anticancer and chemopreventing natural products: some biochemical and therapeutic aspects". J BUON; 15: 627-638.

9. Lao Y, 2005. "Clinical study on effect of matrine injection to protect the liver function for patients with primary hepatic carcinoma after trans-artery chemoembolization (TAE). Zhong Yao Cai 28, 637-638.

10. Lin G, Wu Y, Cai F, Li Z, Su S, Wang J, Cao J and Ma L, 2019. "Matrine Promotes Human Myeloid Leukemia Cells Apoptosis Through Warburg Effect Mediated by Hexokinase 2". Front Pharmacol. 24;10:1069.

11. Liu XY, Fang H, Yang ZG, Wang XY, Ruan LM, Fang DR, Ding YG, Wang YN, Zhang Y, Jiang XL and Chen HC, 2008. "Matrine inhibits invasiveness and metastasis of human malignant melanoma cell line A375 in vitro". Int J Dermatol.;47(5):448-56.

12. Luo C, Zhu YL, Jiang TJ, Lu XY, Zhang W, Jing QF, Li J, Pang LR, Chen KJ, Qiu FM, Yu XY, Yang JH and Huang J, 2007. "Matrine induced gastric cancer MKN45 cells apoptosis via increasing pro-apoptotic molecules of Bcl-2 family". Toxicology 229: 245-252.

13. McMullen CP and Smith RV, 2015. "Treatment/Comparative therapeutics: cancer of the larynx and hypopharynx". Surg Oncol Clin N Am; 24:521-545.

14. Ridge JA, Glisson BS, Lango MN and Feigenverg S, 2010 "Head and Neck tumors". In: Pazdur R, Bagman LD, Camphausen KA, Hoskins WJ (editors). Cancer Management. 12th ed. New York: Multideciplinary approach Medical, Surgical and Radiation and Oncology, The Oncology Group.

15. Si WK and Gao LH, 2001. "Regulation of G-1 phase cell cycle regulation factors in differentiation and apoptosis 
of matrine induced hepatoma cells". Chin J Cancer; 20: $848-851$.

16. Siegel RL, Miller KD and Jemal A, 2016. "Cancer statistics, 2016". CA Cancer J Clin 66: 7-30.

17. Singh B, Alfonso A, Sabin S, Poluri A, Shaha AR, Sundaram K and Lucente FE, 2000. "Outcome differences in younger and older patients with laryngeal cancer: A retrospective case-control study”. Am J Otolaryngol 21: 92-97.

18. Yong J, Wu X and Lu C, 2015. "Anticancer advances of Matrine and its derivatives". Curr Pharm Des.;21(25):3673-80.

19. Yuming Z, Melika S, Shengnan X, Honggang H, Weidong
X and Prasad Shastri V, 2019. "Autophagy inhibition enhances Matrine derivative MASM induced apoptosis in cancer cells via a mechanism involving reactive oxygen species-mediated PI3K/Akt/mTOR and Erk/p38 signaling". BMC Cancer,19 (1):949.

20. Zhou BG, Wei CS, Zhang S, Zhang Z and Gao HM, 2018. "Matrine reversed multidrug resistance of breast cancer MCF-7/ADR cells through PI3K/AKT signaling pathway”. J Cell Biochem.;119(5):3885-91.

21. Zuo GQ, He S and Zhang Y, 2005. "Effects of matrine on telomerase activity and on proliferation of human HepG2 and QGY hepatoma cell lines". J Oncol;11: 126-128. 